\title{
Evaluation and improvement countermeasures of corporate social responsibility
}

\author{
Wei Li, Qi-yan Chen \\ Business school of HoHai University, Jiangsu Nanjing 21009 \\ cqy9713@163.com
}

\begin{abstract}
Enterprise should not only seek the maximized profit for itself, but also take the responsibility they should bear. Enterprise is the significant promoter to develop the societal civilization. Otherwise, it might be cause some problems, such as food security. So we can recognize more urgency of enterprise take charge their responsibility. Assess corporate social responsibility of domestic enterprise, not only can grasp the situation of corporate social responsibility as a whole, but also can improve the core development of the enterprise in many aspects. In order cope with the international corporate social responsibilities' certification better. Therefore, the assessment of corporate social responsibility and how to promote the establishment of enterprises' social responsibility in this article has vital significance.
\end{abstract}

Index Terms - Corporate Social Responsibility Evaluation index Stakeholders Improvement measures

\section{Introduction}

There are many standards on corporate social responsibility on the current international, various international organizations have launched a variety of certification in international trade to restrain and supervise corporate behavior. The author selected CSR evaluation system as the main object of study.

Based on the corporate social responsibility theory of inductive analysis, theory of academic research for corporate social responsibility play a reference for enterprises to promote social responsibility to provide relevant theoretical reference; In practical terms, in line with China's national conditions through the establishment of corporate social responsibility assessment system for corporate social responsibility assessment provides a strong practical approach. In addition, the practice of corporate social responsibility both for self-assessment, but also provide a basis for external assessment of corporate social responsibility, in order to guide the constraint corporate social responsibility, corporate social responsibility to promote the practical application of assessment.

\section{Design and Implementation of Case Study}

A. Choice of Company case study

Company instruction: Refrigeration Equipment Co., Ltd. is a professional home air conditioning manufacturing base. Since its commissioning in 1998, after 10 years of development, the company has become the largest in east China's air conditioner production base, production yields doubled in recent years. Currently employs more than 7,600 people, the annual output of 5.5 million sets of household air- conditioners, the annual output value over 10 billion yuan, led to the emergence and development of a large number of supporting industries. The company is one of the single manufacturing unit in China's largest manufacturer of household air conditioners.

\section{B. Set the Index System of Evaluating Social Responsibility in the Company}

There are 18 indexes in Table I, the measures of safety protection, the rules and regulations of public and system of environmental management are qualitative indexes, the others are quantitative indexes.

\section{Questionnaire Design}

In the actual evaluation, according to the index system and survey requirements of this article, the author designed the "Corporate Social Responsibility Questionnaire", sub-basic situation of enterprises and corporate social responsibility performance situation of two parts, a total of 20 questions related to the 15 indicators data. In the questionnaire design process, select the Likert scale as one of the tools that can ensure high stability index, which has a high reliability; by some regression analysis and correlation analysis tools and by interview learned fulfil corporate social responsibility, the final conclusions broadly consistent with the author's prediction, thus ensuring indicators Questionnaire involved with high validity.

\section{Questionnaire Issued and Recovery}

In the actual sample selection process, I choose managers Refrigeration Equipment Co., Ltd. as the main sample of this questionnaire, the final result of the issuance of 200 questionnaires were valid questionnaires ultimately get is 178 . Job interview

After the end of the survey work, the author has targeted organized a job interview.

\section{CSR Assessment of the Case}

\section{A. The Results of Investigation and Statistics about the Social Responsibility in Refrigeration Equipment Company}

According to a large number of data that came from interviews and questionnaires, we rearrange this and put the result into Table II.

According to the index system of evaluating social responsibility in the company, we weight every index by some specialized analytic methods and put the results into Table III. 


\section{B. Score in the Evaluation of Social Responsibility of Refrigeration Equipment Company}

According to relative received data and evaluating standard, we put the result of score into Table IV.

\section{The Case for Corporate Social Responsibility Fulfilment Situation Specific Analysis}

1) Analysis of Employee Responsibility

Based on Table IV, we can found that the score of employee responsibility is highest, the relative weight in total score is also the highest. The main reason is the average wage of employee is high. Moreover, according to the department of human resource, the average wage of senior managers is also higher than other companies. We can also see that the level of labor contract and social assurance is high in our case.
However, safety protection and the rules and regulations of public are not very good because of the nature of the industry and other reasons, so that the scores of these are not very reasonable.

\section{2) Analysis of Governmental Responsibility}

This refrigerating equipment company has a low credit rating in the government tax records, which is rated 60 between level $\mathrm{C}$ and level $\mathrm{B}$. This is mainly because that the refrigerating equipment company lacks specialized social responsibility management reports and certain annual reports. What is more, the tax rate of total assets has no remarkable score in the level three indexes. Therefore, the scoring criteria of this index require further adjustment and development in the future.

TABLE I The index system of evaluating social responsibility in company A

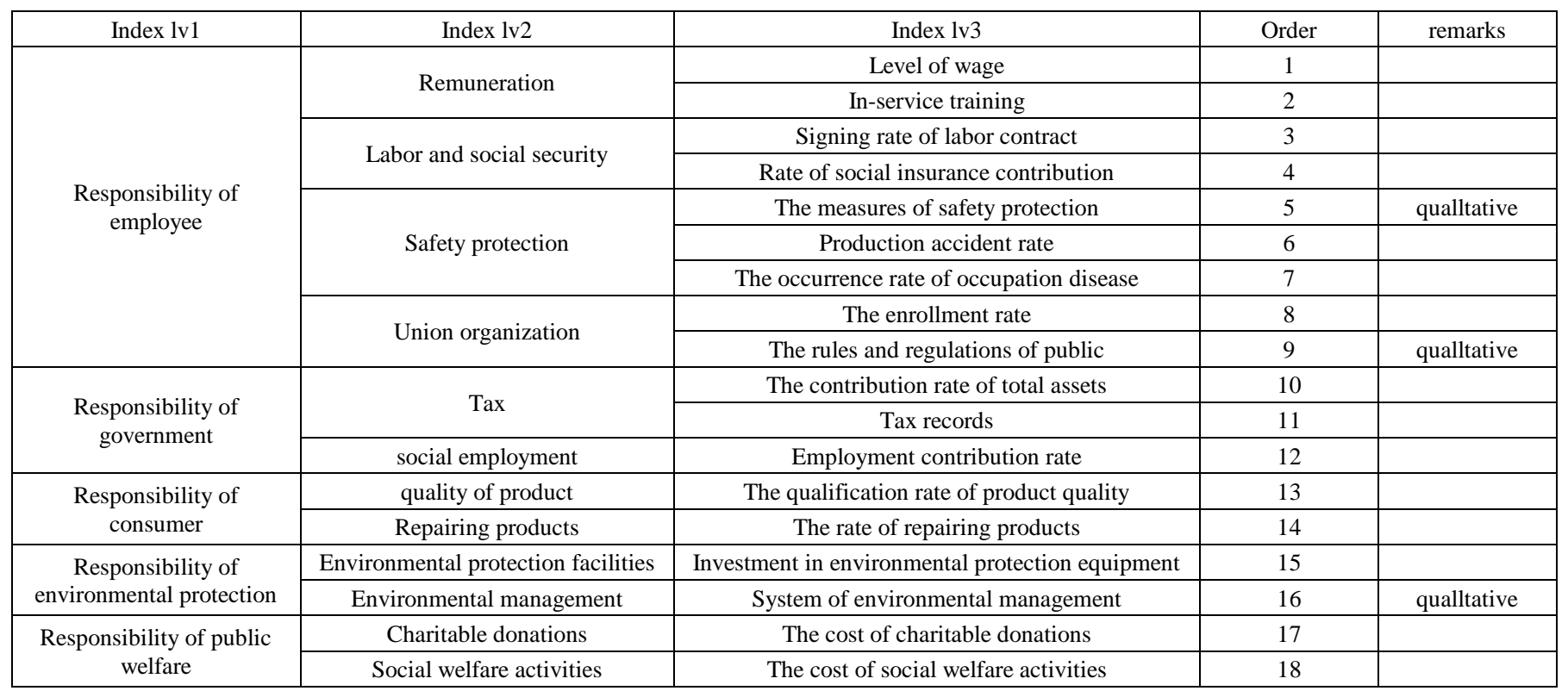

TABLE II The relevant data of refrigeration equipment company

\begin{tabular}{|c|c|}
\hline Title & data \\
\hline Number of employee ( ) & 7600 \\
\hline Average of total assets ( Ten thousands) & 3600000 \\
\hline Average wage of employee (Yuan per month ) & 625 \\
\hline Number of training ( ) & $100 \%$ \\
\hline Signing rate of labor contract & $100 \%$ \\
\hline Rate of social insurance contribution & 0 \\
\hline Production accidents & 0 \\
\hline The percentage of union organization & 0.9171 \\
\hline The qualified rate of production quality & 69523 \\
\hline The rate of Repairing products & 0.9972 \\
\hline Expense of environmental protection equipments (Ten thousands) & 0 \\
\hline Charitable donations (Ten thousands ) & 600 \\
\hline Social welfare activities (Ten thousands ) & 752 \\
\hline Tax record & 0 \\
\hline
\end{tabular}


TABLE III The weight of index system of evaluating social responsibility in the company

\begin{tabular}{|c|c|c|c|c|}
\hline Index lv1 & Index lv2 & \multicolumn{2}{|l|}{ Index lv3 and relative weight } & Weight in the system \\
\hline \multirow{6}{*}{$\begin{array}{c}\text { Responsibility of } \\
\text { employee } \\
0.490\end{array}$} & \multirow{2}{*}{ Remuneration 0.471} & Level of wage & 0.711 & 0.194 \\
\hline & & In-service training & 0.289 & 0.037 \\
\hline & Labor and social security 0.290 & Signing rate of labor contract & 0.481 & 0.059 \\
\hline & \multirow[b]{2}{*}{ Safety protection 0.154} & The measures of safety protection & 0.272 & 0.021 \\
\hline & & Production accident rate & 0.431 & 0.033 \\
\hline & Union organization 0.085 & The rules and regulations of public & 0.583 & 0.024 \\
\hline \multirow{3}{*}{$\begin{array}{c}\text { Responsibility of } \\
\text { government } \\
0.171\end{array}$} & \multirow{2}{*}{ Tax 0.459} & The contribution rate of total assets & 0.688 & 0.054 \\
\hline & & Tax records & 0.313 & 0.025 \\
\hline & Social employment 0.541 & Employment contribution rate & 1.000 & 0.092 \\
\hline $\begin{array}{l}\text { Responsibility of } \\
\text { consumer } 0.225\end{array}$ & Quality of product 0.762 & The qualification rate of product quality & 1.000 & 0.171 \\
\hline
\end{tabular}

TABLE IV Score of social responsibility

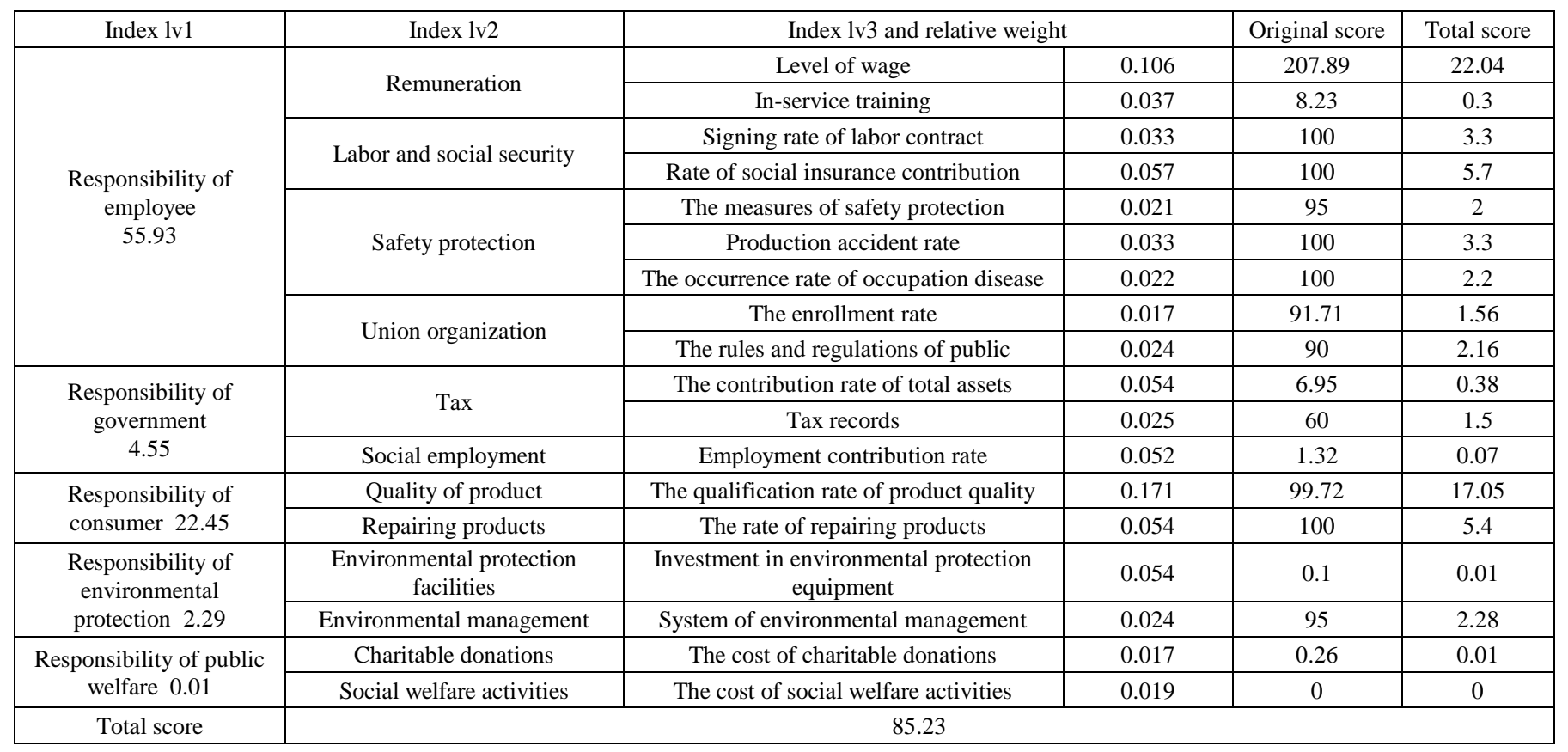

\section{2) Analysis of Governmental Responsibility}

This refrigerating equipment company has a low credit rating in the government tax records, which is rated 60 between level C and level B. This is mainly because that the refrigerating equipment company lacks specialized social responsibility management reports and certain annual reports. What is more, the tax rate of total assets has no remarkable score in the level three indexes. Therefore, the scoring criteria of this index require further adjustment and development in the future.

\section{3) Analysis of Consumer Responsibility}

A small number of indicators of consumer responsibility and account for a large proportion of the total score, the main reason is the excellent quality of products, no rework phenomenon. It can be seen the company is an enterprise responsible for consumers, also reflects the company's focus on customer lifetime value.

\section{4) Analysis of Environmental Protection Responsibility}

As well as the enterprise total assets contribution rate, The data feature score of environmental protection equipment in the overall index system is not obvious. due to the nature of the manufacturing industry this special identity, make the environmental management work is almost impossible to be perfect, So the score of company in the environmental management system is much better than other companies in the same industry. 


\section{5) Analysis of Public Responsibility}

The whole public responsibility score in the proportion, of the total score is extremely low, Because of the social public welfare activities costs too little. Although the public liability is not mandatory, Obligations must be fulfilled, Enterprises to participate in social public welfare activities costs won't produce directly. But from the perspective of marketing, Enterprises to actively participate in social public welfare activities. To establish a good corporate social image, The expansion of market power have great role in promoting. Company as an integral part of the community, Undertake appropriate public responsibility, Can improve the image of the enterprise itself, Strengthen the recognition of the customers.

\section{The Practical Application of Corporate Social Responsibility Evaluation System}

Index evaluation system constructed in this paper can be used in the industry of local governments in the region to evaluate other enterprises perform their social responsibility, and according to the score is divided into $\mathrm{A}, \mathrm{B}, \mathrm{C}, \mathrm{D}, \mathrm{E}$ five levels of management. level of 90 points or more is A, B level is $80-89$ points , $\mathrm{C}$ level is $70-79$ points, $\mathrm{D}$ for $60-69$ points, , $\mathrm{E}$ for below 60 points. For some enterprises can well fulfil the social responsibility should have some reward for encouraging policy, for some in the performance of the social responsibility with negligence can strengthen the enterprise's emphasis on this aspect.

\section{Suggestions for Improving Social Responsibilities of a Corporation}

\section{A. External Suggestions for Improvement}

1) Joint management of professional social institutions and government departments. Corporations need to communicate well with international institutions and guarantee successful product circulation, with which establishing professional social institutions can cope. The way of evaluating and managing social responsibilities of enterprises by category management could not only encourage corporations to fulfil their social responsibilities, but also enhance recognition of international society and promote communication.

2) Strengthen supervision of social public opinions. Founding strong public opinion system by allowing active social discussion of the public, with the help of the media who express themselves in public, could supervise the enterprises and push them to fulfil their responsibilities better.

\section{B. Internal Suggestions for Improvement}

For an enterprise, undertaking social responsibilities may seemingly enlarge the cost and the profit it brings is not visible in the short term. However, in the long term, undertaking social responsibilities, which is essential to comprehensive and further development of an enterprise, is beneficial to establish good social image and achieve social recognition, as well as accordingly expand market influence and promote further development.

Consequently, we advice enterprises to cultivate the awareness of actively bearing social responsibilities, accepting international responsibility inspect and striving for initiative in the international trade.

\section{Conclusion and Prospect}

\section{A. Conclusion}

Evaluation on social responsibilities which the enterprises in our country are bearing helps to grasp their circumstance of fulfilling social responsibilities from a macro. It urges the enterprises to fulfil corresponding social responsibilities, as well as handle social responsibility recognition work of the international enterprises better, accordingly achieve initiative in the international competition while chasing for maximum profit. Therefore, this paper is significant to evaluation on social responsibilities of the enterprises and how to promote the construction of them.

Corporate social responsibility implementation to our country is a new comprehensive system engineering. Government enterprise itself and the social public three aspects should be in accordance with their respective functions and requirements common attention and joint efforts, then we can effectively promote corporate social responsibility to develop in depth, and guide the enterprise bear the social responsibility actively, so as to promote the harmonious development of society.

\section{B. The Deficiency and Prospects}

The selection of corporate social responsibility evaluation system index also need to consider further perfect. Due to the complexity of our country, Different regions, Enterprises of different sizes, Different industries, such as the evaluation index of corporate social responsibility have different understanding and requirement These factors are not included in this study. In addition, individual indicators scoring criteria to be further revised and improved, overall, CSR evaluation system constructed in this paper is sketchy, Research results and practical application there is a gap, The latter will continue to study the deficiencies.

\section{References}

[1] Wang Yang. System construction of our country Corporate Social Responsibility management system. Academic BBS. 2008,03.

[2] Su Yamin, National regional enterprises to fulfil the social responsibility of countermeasures. Financial supervision,2011,07.

[3] [US] Peter drucker. The practice of management, QIruolan translant. Mechanical industry press, Beijing,2006.53

[4] N. Leila Trapp. Stakeholder involvement in CSR strategy-making? Clues from sixteen Danish companies,2014,(40):42-49

[5] Tian Hong. Corporate social responsibility and its propulsion system. Economic management publishing house, Beijing,2006

[6] Theodore Metaxas, Maria Tsavdaridou. CSR in metallurgy sector in Greece: A content analysis, 2013, (38):295-309

[7] Carroll, A.B.A. Three-Dimensional Conceptual Model of Corporate Performance. Academy of Management Review,1979,4(4):497-50. 